\title{
THE FUNCTIONAL COST ANALYSIS AS A METHOD OF ANALYSIS OF PERSONNEL MANAGEMENT SYSTEM AT DOMESTIC ENTERPRISES
}

\section{Kainara D.O., Metelskaya N.S.}

Zaporizhzhia National University

Ukraine, 69600, Zaporizhzhia, Zhukovsky str., 66

kainara1992@gmail.com, metelska1996@gmail.com

\section{ORCID 0000-0002-4061-8409, 0000-0003-1191-6463}

Key words:

functional-cost analysis, personnel management system, function, stages of functional-cost analysis, traditional methods of analysis, cost analysis.
The article deals with the peculiarities of application of functional-cost analysis of the personnel management system, including the identification of unnecessary or duplicate management functions; functions that have not been performed for any reasons; the degree of centralization and decentralization of management functions has been determined. The main difficulties which specialists are facing in conducting FCA have been revealed. The advantages and disadvantages of this method have been identified. The experience of foreign countries in using of functional-cost analysis, as well as practical application in the enterprises of Ukraine has been analysed. The authors propose an approach by which the efficiency of personnel management at the enterprise will be considered comprehensively and systematically, using such basic structural elements as a system with an arbitrary number of elements and connections, its subsystem, the beneficial effect of their function by appointment. The article proposes an evaluation method that reflects the efficiency and productivity of staff. The status of the activity of an individual department or employee has been suggested to be described as a set of functions and the cost of providing them. The importance of each individual function in the value expression for the general financial condition of the enterprise has been emphasized in order to supplement the previously formed functional structure for finding alternative solutions. It has been determined that the existing experience in the application of functional cost analysis in the field of personnel management is imperfect. Therefore, it requires further elaboration in the form of methodological and practical recommendations, taking into account foreign experience. The conclusion has been made about the necessity of wider application of functional-cost analysis, creation of special services of enterprises, as well as strengthening of functional relations of such services with managers and other departments at the enterprise.

\section{ФУНКЦІОНАЛЬНО-ВАРТІСНИЙ АНАЛІЗ ЯК МЕТОД АНАЛІЗУ СИСТЕМИ УПРАВЛІННЯ ПЕРСОНАЛОМ НА ВІТЧИЗНЯНИХ ПІДПРИЄМСТВАХ}

\author{
Кайнара Д. О., Метельська Н.С. \\ Запорізький національний університет \\ Україна, 69600, м. Запоріжжс, вул. Жуковського, 66
}

\section{Ключові слова:}

функціонально-вартісний аналіз, система управління персоналом, функція, етапи проведення функціонально-вартісного аналізу, традиційні методи аналізу, аналіз вартості.
Розглянуто особливості застосування функціонально-вартісного аналізу системи управління персоналом, зокрема виявлення зайвих або дублюючих функцій управління; функцій, які 3 певних причин не виконуються; визначається ступінь централізації і децентралізації функцій управління. Виявлено основні труднощі, з якими стикаються фахівці при проведенні ФВА. Визначено переваги і недоліки цього методу. Проаналізовано досвід зарубіжних країн у використанні функціонально-вартісного аналізу, а також практичне застосування на підприємствах України. Розглянуто підхід, за яким ефективність управління персоналом на підприємстві розглядатиметься комплексно та системно, використовуючи такі основні структурні елементи, як система 3 довільною кількістю елементів і зв'язків, iï підсистема, корисний ефект їх функціонування за призначенням. Запропоновано метод оцінювання, який відображає ефективність та продуктивність роботи персоналу. Діяльність окремого відділу або працівника пропонується описати як сукупність функцій та витрати на їх забезпечення. Окреслено важливість кожної окремої функції у вартісному вираженні для загального фінансового стану підприємства, щоб доповнити раніше сформовану функціональну структуру пошуку альтернативних рішень. Визначено, що існуючий досвід застосування функціональновартісного аналізу у сфері управління персоналом $є$ недосконалим. Отже, він потребує доопрацювання у вигляді розробки методичних та практичних рекомендацій з урахуванням закордонного досвіду. Зроблено висновок про необхідність розширеного застосування функціонально-вартісного аналізу, створення спеціальних служб на підприємствах, а також укріплення функціональних зв'язків таких служб з керівниками та іншими відділами на підприємстві. 


\section{Statement of the problem}

Effective management requires not only the optimization of production, which, in its turn, involves the reduction of the cost of the producing of products and requires complete analysis and diagnosis, but also the optimization and modernization of personnel cost management methods. Many methods of such analysis are used in international and national methodology and practice, one of which is the Functional Value Analysis (FCA). The FCA is a practical application of a comprehensive systematic study of objects, aimed at ensuring minimal costs for their production and sale, under the condition of maintaining the necessary consumer properties.

\section{Analysis of recent studies and publications}

According to the study of G.S. Koshevetskaya [1], functional-cost analysis is one of the effective tools that enable the complex to solve the problem of economy of resources, competitiveness of enterprises, achievement of production efficiency and productivity of staff. If properly justified and applied, the cost of performing the functions of an individual employee or department will be reduced by an average of $20-25 \%$, which is significantly more effective than using other methods of cost optimization of the organization [1, pp. 358-359].

M. Bakanov [2] notes the high efficiency of functionalcost analysis in the process of formation of technical and economic parameters of new products, in the preparation and decision-making by management.

O.M. Kostenko [3] considered the possibility of using functional-cost analysis in various spheres of economic activity. V.V. Rovenskaya investigated the stages of development of functional-value analysis.

I. Grigorash [4] states the need of the using of the FVA in controlling and its main features in comparison with traditional systems of calculation.

V. Maltiz [5] considers functional-cost analysis as one of the effective ways of increasing the personnel potential of the enterprise.

\section{Objectives of the article}

The identification of the main trends in the use of functional cost analysis in the world market will allow domestic enterprises to reach a higher level by means of new, innovative and modern methods and practices in the field of personnel management.

\section{The main material of the research}

The market economy, which is becoming more and more widespread, is leading to fundamental changes in the management system of enterprises and organizations. The quality of personnel management is a consequence of such changes that require new approaches. In this regard, the activities of enterprises are increasingly paying attention to improving the efficiency of personnel management. In each organization, there has always been a department that was a subsystem of personnel management, but its development was not in priority, as human resources management was structurally interconnected with other units, and as a result it was not a focal point for staffing.

However, the issue of the Human Resource Department development provoked the increasing of the interest in new methods and approaches in personnel management.
Contemporary management ideas are based on the fact that staff needs to be clearly analysed and improved. One of the effective methods of description, control, analysis and improvement of the personnel of the enterprise is the method of the functional cost analysis (FCA).

Functional cost analysis is a method of systematic object research, which is based on the analysis of costs for individual functions of labour or production process, that allows to increase the efficiency of use of material and labour resources [6].

The advantage of this method is that it can be applied both to machines and to the workforce, because their work is not always optimal and there can be a human factor [6].

The FCA refers to promising methods of economic analysis. It successfully uses advanced techniques and elements of engineering, logical and economic analysis. A great feature of this method is its high efficiency. As practice shows, with the proper application of the FCA, the cost of production is reduced by an average of $20-25 \%$.

The functional approach, which is one of the components of the FCA, analyses the quantitative and qualitative aspects of the specific needs of customers to maximize the work of the personnel department or production.

Function, which is relative functional-value analysis, is an external expression of the properties of any object in the system of relations [6, p. 27]. Functions performed by the object can be divided into basic, auxiliary and unnecessary. Basic functions determine the purpose or basic responsibilities of the employee or department in the enterprise. Auxiliaries are functions that perform or complement basic functions. Unnecessary functions do not contribute to the fulfilment of the main purpose, but, conversely, have a poor effect on the efficiency and productivity of execution [6].

On this basis, the main purpose of the FCA is to develop useful functions of the object with the optimal correlation between their importance for the consumer and the cost of their implementation.

During the development of functional cost analysis, the areas in which it was applied changed. With regard to human resources, the methodology of this analysis allows you to analyse and improve the assigned functions for a particular unit or worker. Such functions in the sphere of enterprise management can be: planning, forecasting, accounting, control, monitoring, coordination. The organizational structure of the management apparatus is the composition, interconnections and subcontracting of these functions.

Basing on the principles of functional cost analysis, the personnel management system of the organization is a continuous process of improving the principles and methods of working with the personnel of the enterprise, whose main purpose is to create the conditions for their most effective using. During the consideration of the issues of functional-cost analysis, it is possible not to consider the issues which are related to the formation of personnel management costs. The study of theoretical material showed that in the ranks of modern scientists there is no unity in the definition of the concept of personnel costs. This fact can explain the difference in the views and approaches of researchers of this problem. 
Personnel costs in the organization are an element of the cost of social production, which is formed as a result of the use of labour resources of the enterprise. On the other hand, it is proposed to consider the cost of personnel of the enterprise as a complex concept, consisting of the totality of the cost of the employer and the cost of citizens to create the necessary conditions for work. Under the cost of personnel of the enterprise offers to understand the formation of a certain funds, which in the future is directed to the development of staff and his ability to work. It classifies personnel management expenses as the amount of remuneration, expressed both in kind and in monetary forms, transferred by the employer to the employee for the work performed. It characterizes personnel costs as an integral aggregate indicator, which takes into account the costs incurred by the enterprise in the process of search, involvement, organization of working conditions, material and social security, as well as the dismissal of employees [7].

The successful solution of the FCA method control problems is done due to the fact that the functions which are performed by the individual components of the management system and officials specify and as a result, the quality of managerial decision-making is improved, as well as the personnel, information and technical support of the management system, which also contributes to lower costs and increase competitiveness in the market. But functional-cost analysis will not be effective if it is not strictly followed, it has 7 steps (Fig. 1), which must be performed sequentially, each of them has its unique value, so avoiding at least one stage can lead to losses and inaccurate results.

Stages of functional cost analysis

Preparatory stage. At this stage the object of analysis is specified.

Information stage. Provides collection of information about the object being studied: purpose, technical capabilities, quality, cost.

The analytical stage. It involves studying the functions of an individual worker or unit and the cost of providing them.

Creative stage. The search for ideas and variants of solutions that ensure the elimination of harmful and neutral, combining useful functions and reducing the cost of the object.

The research stage. Provides an assessment of ideas and variants of decisions which were made in the previous stages in order to eliminate disparities between functions and costs.

Recommendation stage. It is associated with the selection of the most appropriate work methodologies.

Stage of implementation. It is conclusive during the considering of the results of the recommendation stage and implementing of the selected variant of improvement of tactics and strategy of work.

Fig. 1. Stages of functional cost analysis (developed by author, it is based on the sources [6; 7])

The development of functional cost analysis has been widely used in management accounting. First, due to the systematic method, which allows to determine the structure of the object under study, to divide it into components, to give them a double assessment: from the consumer point of view to the cost of quality of the whole, and from the cost of production costs. Due to the systematic approach of functional-cost analysis, it is possible to distinguish the object which is under the study, the cause and effect relationship between the quality of production and the cost. As a result, there are reasons to remove mechanical planning methods from the 
established standards that is based on the generated labour cost and cost of materials.

During the implementation of the results of functional cost analysis, the following main tasks have been solved:

- increasing productivity and efficiency of work processes;

- reducing the cost of doing unnecessary value-adding functions;

- increasing competitiveness;

- improving the quality of products, including improving the work of staff or a part of it;

- developing new or improving existing management systems at the enterprise;

- reducing the risks that are associated with the untimely execution of work.

In world practice, interest in the FCA was conditioned by its practical value. The emphasis of the costs by types of activity is based on the functional analysis and value engineering that was widely used in practice, in particular, the high efficiency of this approach was proved by American specialists of the company "General Electric"; in Germany in 1960-1980 it was used by the companies "Opel" and "BMW"; in Japan this method has been implemented since the mid-1970s and covers 80-90 percent of newly developed products. According to the calculations of American specialists, every dollar invested in the FCA brings $\$ 10$ of net profit [8, pp. 91].

Functional value analysis has become the most widely used method in the United States. The US companies use this method as their primary by means of increasing their product competitiveness and increasing of profits. The functional cost analysis provides saving that is in many times greater than the cost of the analysis itself. In the United States, in 1959, in order to improve the work of industry, was created a society of American engineersspecialists. In the initial period of the FCA development in the USA, two different forms of application of the method were established. In the first case, there were already existing products that needed cost analysis, and the second form was used in the forming of cost. Initially, in the 1960s, the FCA in the United States was widely used as a method of checking the enforcement of federal laws by government agencies. Foreign companies even started to set up special departments that were engaged in functional-value analysis, which were permanent groups. Temporary, the FCA teams were staffed with specialists who had the technique and represented the core services of the enterprise.

Currently, in the United States, the FCA method has been improved, and it has been implemented a system that is called FAST. The basis of this technique is not only the identification and formulation of functions, but also the verification of the correct classification, the establishment of relationships between functions. The advantages of the FAST methodology include such an opportunity as a visual representation of the relationship of functions, as well as creating conditions for improving the organization of the FCA, including improving communication between performers [8].

The FCA is also most successfully used in Japan and Japanese enterprises. The introduction of functional value analysis requires creative, collective thinking, which is quite easy in the work of Japanese enterprises operating through the "family" principle. Therefore, in comparison with Western European countries, they pay more attention to addressing promising issues and long-term programs.

According to personnel in Japan, the FCA initially was used in the 1960s. From the point of view of Japanese experts, this scope is influenced by two specific trends: the expansion of competition for efficiency and competition for the "cultivation of a new era." The first direction is connected with the efficiency and productivity of staff, the second one is connected with the creation of fundamentally new products of high consumer value and utility.

In Western Europe, the most active users of the FCA can be considered the companies of Austria and the Federal Republic of Germany, where since 1973 there has been a national standard for these works (DIN 6990).

One of the largest industrial companies which were behind the origins of the FCA is the West German firm Siemens (Germany). The experience of using FCA at Siemens shows that it has achieved an average cost reduction of 10$20 \%$ in the early 1980 s [8].

The functional cost analysis is an innovative method that identifies cost savings reserves and is based on finding cheaper ways to perform the major functions (through organizational, technical, technological and other production changes) and eliminating unnecessary functions at the same time. The FCA is a powerful tool for improving efficiency of production, strengthening product competitiveness, and saving resources.

All modern companies and enterprises in the world use functional-cost analysis as a way of maintaining quality of management that meets the world quality standards of ISO 9000 .

In Ukraine, the functional cost analysis is widely known and used in such fields as electronic, coal, industrial, mechanical engineering, electrical engineering. This method is one of the most popular methods of reducing cost reserves. But the use of this method in the management accounting and in the modern economic development requires the development of methodological and practical recommendations, taking into account the specifics of the work with personnel. The main tasks of such developments at the present stage include: acquaintance of workers with procedure of functional and cost analysis; giving the opportunity to the specialists to acquire the necessary skills in the practical application of functional-cost analysis in solving specific problems; substantiation of the economic consequences from using the FCA and displaying their relationship with improved production efficiency.

Therefore, the functional cost analysis is one of the most popular modern methods of reducing costs in the enterprise. It is based on the fact that in each object or system, that should be analysed, there are both relevant to existing developments but and unnecessary costs.

\section{Conclusions}

In conclusion, summarizing all information, that was performed, it should be noted that the effectiveness of the application of functional-cost analysis in domestic 
enterprises, that is relative to staff, depends totally on the organizational, methodological, economic and sociopsychological conditions that are designed to provide the necessary quality and costs based on improving the level of management; involvement of all specialists in this process, systematic use of modern ways of finding the most effective solutions to ensure product quality. Close interaction, creative business cooperation between the FCA services and other economic and scientific-technical units, integration of their activities are necessary elements of management organization that are based on the FCA method.

\section{References}

1. Koshevetskaya, G.S. (2015). Vykorystannia funktsionalno-vartisnoho analizu z metoiu vyiavlennia rezerviv pidvyshchennia efektyvnosti vyrobnytstva [Use of Functional Value Analysis to Identify Reserves for Increasing Production Efficiency]. Dnepropetrovsk: DNU[in Ukrainian].

2. Bakanov, M. I. (2016). Teoriya ekonomicheskogo analiza [Theory of economic analysis]. Moscow: Finance and Statistics[in Russian].

3. Kostenko, O.M. (2009). Funktsionalno-vartisnyi analiz v upravlinni finansovoiu rezultatyvnistiu silskohospodarskykh pidpryiemstv [Functional-cost analysis in the management of financial performance of agricultural enterprises]. Visnyk KhNAU im. V.V. Dokuchaieva - Bulletin of KhNAU V.V. Dokuchaev, 12 (2), 143. Retrieved from: www.nbuv.gov.ua/portal/Chem_Biol / Vkhnau / Tn / 2009_12 / ... /12_26.pdf

4. Grigorash, I.O. (2012). Metod funktsionalno-vartisnoho analizu v kontseptsii kontrollinhu [Method of Functional Value Analysis in the Concept of Controlling]. Visnyk KNEU im. V. Hetmana - Bulletin of KNEU V. Hetman, 10, 15. Retrieved from: http://www.kneu.kiev.ua/data/upload/publication/main/ en/717/grogorash.doc

5. Maltiz, V.V. (2019). Shliakhy pokrashchennia kadrovoho potentsialu v suchasnykh umovakh [Ways to improve human resources in the current environment]. Visnyk ZNU - Bulletin of ZNU, 9,122-127 [in Ukrainian].

6. Moiseeva, N.K., \& Karpunin, M.G. (2008). Osnovyi teorii i praktiki funktsionalno-stoimostnogo analiza [Fundamentals of the theory and practice of functional-cost analysis]. Moscow: tutorial [in Russian].

7. Kobzeva, V.V. (2018). Manevrennist zatrat na upravlinnia personalom [Maneuverability of personnel management costs]. Kirovohrad: A lecture course [in Russian].

8. Shatunova, G.A. (2018). Istoryko-lohichnyi henezys ta periodyzatsiia etapu potrebuiut funktsionalno-vartisnoho analizu [Historical-logical genesis and periodization of a stage require functional-value analysis]. Visnyk SDEU Bulletin of SDEU, 11, 91-96 [in Russian]. 